\title{
Association of colonoscopy and histopathological findings of the canine large intestine and ileum abnormalities: 54 cases series ${ }^{1}$
}

\author{
Angélica C. Ferreira² (D), Ana L.F. Bicalho ${ }^{3}$ (D) Felipe Pierezan ${ }^{4}$ (D), Sóstenes A.C. Marcelino² (D), \\ Raphael R. Wencesalu ${ }^{4}$ (D) Rafaela S. Prestes ${ }^{2}$ (D) , Renato C.S. Torres ${ }^{4}$ (D) \\ and Anelise C. Nepomuceno ${ }^{4 *}$ (D)
}

\begin{abstract}
Ferreira A.C., Bicalho A.L.F., Pierezan F., Marcelino S.A.C., Wencesalu R.R., Prestes R.S., Torres R.C.S. \& Nepomuceno A.C. 2021. Association of colonoscopy and histopathological findings of the canine large intestine and ileum abnormalities: 54 cases series. Pesquisa Veterinária Brasileira 41:e06741, 2021. Departamento de Clínica e Cirurgia Veterinária, Universidade Federal de Minas Gerais, Campus Pampulha, Av. Pres. Antônio Carlos 6627, São Luiz, Belo Horizonte, MG 31270-901, Brazil. E-mail: anelise-imagem@ufmg.br

Colonoscopy is a minimally invasive technique used to assess the large intestine through direct inspection of the intestinal mucosa. When associated with histopathological examination of fragments collected from the intestine, the definitive diagnosis can be obtained. This retrospective study evaluated colonoscopy and histopathological exams of the large intestine and ileum of dogs with gastrointestinal disorders admitted at the Veterinary Hospital of the Federal University of Minas Gerais (UFMG) and the Veterinary Hospital São Francisco de Assis to determine the frequency of injuries, their distribution in the intestinal segments, and the relationship of the findings observed in these two analyzes. The colonoscopy and histopathological findings of the case series were described using absolute and relative frequencies, as well as nature and intensity classification of the findings. Cohen's Kappa coefficient was obtained to assess the concordance of nature and intensity classifications between colonoscopy and histopathology, and its 95\% confidence interval constructed. The analyses were performed using the Software SAS University Edition. It was observed a moderate agreement between the classification of the nature of the findings by endoscopy and histopathology (Kappa coefficient $=0.39, \mathrm{CI}=0.20-0.59$ ). This can also be observed when assessing the frequency of similar diagnoses between the methods, since only 39 (72.22\%) were consistent, i.e., $15(22.78 \%)$ diagnoses differed depending on the nature of the finding, which could have a great influence on the final diagnosis if histopathology was disregarded. For the intensity of the injuries, little agreement was observed between the methods (Kappa coefficient $=0.1243, \mathrm{C}=-0.05-0.30$ ). This was even more evident in the frequency of similar diagnoses in terms of intensity, of which $20(37.04 \%)$ were similar and $34(62.96 \%)$ were different. Inflammatory affections are the most frequently observed alterations in the large intestine and ileum of dogs. The most common finding that reveals inflammatory changes is the lymphoplasmacytic infiltrate. As for the proliferative and neoplastic lesions, adenomatous polyps and lymphoma were common. The most affected sites of the large intestine were the descending colon and the rectum. Findings such as edema and reddening of the mucosa were frequent by macroscopy. Although the changes observed by colonoscopy and histopathology may not be similar, these techniques are complementary, which makes biopsies mandatory for a diagnostic conclusion.
\end{abstract}

INDEX TERMS: Colonoscopy, histopathology, canine, large intestine, ileum, endoscopy, intestinal disorders, dogs.

\footnotetext{
${ }^{1}$ Received on August 5, 2020.

Accepted for publication on August 17, 2020.

${ }^{2}$ Graduate Program in Animal Science, Departamento de Clínica e Cirurgia Veterinária, Universidade Federal de Minas Gerais (UFMG), Campus Pampulha, Av. Pres. Antônio Carlos 6627, São Luiz, Belo Horizonte, MG, 31270-901, Brazil.
}

\footnotetext{
${ }^{3}$ Hospital Veterinário São Francisco de Assis, Rua Espírito Santo 2143, Lourdes, Belo Horizonte, MG 30160-032, Brazil.

${ }^{4}$ Professor, Departamento de Clínica e Cirurgia Veterinária, Universidade Federal de Minas Gerais (UFMG), Campus Pampulha, Av. Pres. Antônio Carlos 6627, São Luiz, Belo Horizonte, MG 31270-901, Brazil. *Corresponding author: anelise-imagem@ufmg.br
} 
RESUMO.- [Associação de achados de colonoscopia e histopatologia do intestino grosso e íleo de cães: série de 54 casos.] A colonoscopia é uma técnica pouco invasiva utilizada para avaliação do intestino grosso por meio de inspeção direta da mucosa intestinal. Quando associada ao exame histopatológico, com a coleta de fragmentos do intestino, o diagnóstico definitivo pode ser obtido. 0 objetivo desse estudo retrospectivo foi associar os achados de exames de colonoscopia e histopatologia do intestino grosso e íleo em 54 cães com distúrbios gastrointestinais dos Hospitais Veterinários da Universidade Federal de Minas Gerais (UFMG) e São Francisco de Assis. Na colonoscopia, as alterações mais frequentemente observadas foram edema, friabilidade e avermelhamento de mucosa. Quanto à distribuição de lesões por segmento intestinal, houve maior incidência de alterações inflamatórias, das quais foram as mais frequentes, com o infiltrado linfoplasmocitário sendo o mais comum em todos segmentos analisados (i.e. reto, cólon, ceco e íleo). 0 cólon ascendente e o reto foram os locais de alterações mais frequentes na colonoscopia e na histopatologia. Os pólipos hiperplásicos e o linfoma foram as lesões proliferativas de ocorrência mais comum. Houve baixa concordância entre as classificações por natureza e intensidade dos achados na colonoscopia e histopatologia. Assim, não foi possível associar alterações descritas nos exames histopatológicos quanto à natureza e intensidade das lesões utilizando a colonoscopia, o que leva à conclusão de que é essencial a realização de biópsias em todos os exames para conclusão diagnóstica.

TERMOS DE INDEXAÇÃO: Colonoscopia, histopatologia, intestino grosso, íleo, caninos, endoscopia, desordens intestinais.

\section{INTRODUCTION}

The intestine can be affected by several inflammatory, neoplastic, infectious, and degenerative diseases, and may show alterations in terms of anatomy and function, as well as changes associated with foreign bodies. The clinical signs in these diseases are nonspecific and include changes in appetite, vomiting, weight loss, diarrhea, tenesmus, hematochezia, and mucus stools (Jergens et al. 2003). Therefore, imaging exams are essential for accurately diagnosing such diseases, as they allow for the determination of the location, the probable nature, and the severity of the injury (Silva et al. 2009).

Among the imaging techniques, colonoscopy with a flexible endoscope stands out for the evaluation of persistent chronic colorectal disorders such as tenesmus, hematochezia, and mucus feces (Elwood 2003, Jergens et al. 2003). This non-invasive technique allows for the visualization of the mucosa of different intestinal segments and biopsies (Nahas et al. 2005). In dogs, it allows the evaluation of the rectum, colon, cecum, cecocolic and ileocolic valves, and, in some cases, the ileum (Miki Jr et al. 2002). Colonoscopy assesses the macroscopic characteristics of the changes, which may sometimes be inconclusive (Sherding 2003, Parnell 2009, Santos et al. 2009). Definitive diagnosis is usually made by characterizing the lesion through the histopathological examination of the fragments collected during the procedure and correlating with the clinical signs and response to treatment (Willard et al. 2008).

Inflammatory processes are frequently observed in these exams and, from the histopathological point of view, are named according to the type of the infiltrate present in the lamina propria. The lymphoplasmacytic infiltrate is the most frequent in small animals (Maeda et al. 2012, Rossi et al. 2015). The eosinophilic infiltrate is the second type that affects small animals the most and can occur alone or in association with other infiltrates (Parnell 2009). Eosinophilic inflammation can be seen in cases of parasitosis and food intolerance and/or allergy, despite being an unspecific lesion. Other inflammatory infiltrates such as neutrophilic, granulomatous, and mixed (lymphoplasmacytic and histiocytic, lymphoplasmacytic and neutrophilic, lymphoplasmacytic, and eosinophilic) may also occur (Willard et al. 2008). On the other hand, processes such as histiocytic ulcerative colitis (HUC), characterized by infiltration of tumefied histiocytes in the lamina propria and submucosa with intracytoplasmic deposits of PAS-positive material, are less common. In addition to their impacts on the function of the intestinal mucosa and on the intestinal microbiota, these inflammatory changes are of clinical significance because they are predisposing factors to the onset of intestinal lymphangiectasia, and cause malabsorption and loss of proteins (Sherding \& Johnson 2006).

Dysbiosis is an imbalance in the composition of the intestinal microbiota, and veterinary studies have associated it with several gastroenteric disorders, such as inflammatory bowel disease (IBD) and granulomatous colitis (German et al. 2000, Suchodolski 2016, Minamoto et al. 2014). The loss of commensal bacterial microbiota in acute and chronic intestinal diseases has been related to changes in immunomodulatory bacterial metabolites, such as short-chain fatty acids and secondary bile acids (Suchodolski 2016), as well as the presence of enterotoxic bacteria from the Clostridium hiranonis group (Minamoto et al. 2014, AlShawaqfeh et al. 2017). Neutrophilic infiltration may be present in cases of infections by Clostridium spp. and Campylobacter jejuni (Simpson \& Jergens 2011), and co-infections with intestinal or protozoan parasites may also occur (Casanova et al. 2019).

Few studies have carried out a comparative analysis of endoscopic and histopathological methods for general conditions that affect the large intestine and the ileum of dogs. In general, studies emphasize a specific intestinal lesion and no consensus on the association between the techniques is presented (Roth et al. 1990, Larson et al. 2012, Cascon et al. 2017).

The present retrospective study evaluated colonoscopy and histopathological exams of the large intestine and ileum of dogs with gastrointestinal disorders admitted at the Veterinary Hospital of the "Universidade Federal de Minas Gerais" (UFMG) and the Veterinary Hospital São Francisco de Assis (Belo Horizonte/MG, Brazil) from January 2013 to October 2018 to determine the frequency of injuries, their distribution in the intestinal segments, and the relationship of the findings observed in these two analyzes.

\section{MATERIALS E METHODS}

Our survey included 54 colonoscopies and histopathology exams of dogs admitted at the Veterinary Hospital São Francisco de Assis $(n=48)$ and the Veterinary Hospital of the "Universidade Federal de Minas Gerais" (UFMG, n=6) from January 1, 2013 to October 31,2018 . Both hospitals are located in the city of Belo Horizonte, Minas Gerais, Brazil. This retrospective study analyzed data from an already established database and, therefore, did not require approval by an Ethics Committee on the Use of Animals. The information collected from the colonoscopies and histopathological exams 
were: year of procedures, name, species, breed, sex, age, clinical suspicion, findings in the intestinal segments, nature and intensity of the described changes, and diagnostic conclusions. Based on the diagnostic conclusion of the colonoscopy and histopathology reports, the information was grouped according to its nature (inflammatory, neoplastic, of undefined or mixed cause) and the intensity of injuries (mild, moderate, or intense).

Colonoscopy exams were performed by two operators with the animal under general anesthesia, and 23 alterations were considered for classification: friability, enanthem, edema, ulcer, erosion, hemorrhagic focus, nodule or mass, hematoma, clot in the lumen, parasite, hyperreflexia, pinkish-reddish color, whitish coloration, blackish coloration, reddish coloration, irregular surface, mucosa pleating, velvety appearance, presence of mucus, fibrosis, evident lymphoid follicles, reduced distensibility, and granular aspect. These alterations were present in inflammatory, neoplastic, or infiltrations of undefined or mixed causes, according to Washabau et al. (2010).

The collections of intestinal fragments were performed, when possible, in the anus, rectum, descending colon, transverse colon, ascending colon, and ileum segments using biopsy forceps through the endoscope working channel. For histopathological examination, changes were considered according to Day et al. (2008) and Willard (2012). The hematoxylin and eosin (HE) stain was used.

The colonoscopy and histopathological findings of the case series were described using absolute and relative frequencies, as well as nature and intensity classification of the findings. Cohen's Kappa coefficient was obtained to assess the concordance of nature and intensity classifications between colonoscopy and histopathology, and its 95\% confidence interval constructed. The analyses were performed using the Software SAS University Edition (SAS 2018).

\section{RESULTS E DISCUSSION}

In the colonoscopy reports, information was collected from the macroscopy of the following intestinal segments: rectum (47/54), descending colon (49/54), transverse colon (47/54), ascending colon (48/54), cecum (12 / 54), ileum (10/54), cecocolic valve $(3 / 54)$, ileocecal valve $(9 / 54)$, and anus $(2 / 54)$, totaling 214 analyzed segments. The number of segments analyzed per dog varied from one to seven: one dog had seven segments analyzed, six dogs had six segments analyzed, 16 dogs had five segments analyzed, 18 dogs had four segments analyzed, three dogs had three segments analyzed, one dog had two segments analyzed, and eight dogs had only one segment analyzed.

In the 54 reports analyzed, information on injuries was observed in 198 histopathological fragments of tissues collected from seven segments: rectum (36/54), descending colon (35/54), transverse colon (35/54), ascending colon $(35 / 54)$, cecum $(15 / 54)$, ileum $(31 / 54)$, anus $(11 / 54)$. The ileocolic and cecocolic valves were evaluated exclusively by colonoscopy, since sphincter biopsies are not recommended, and should be performed only in the adjacent region. From the collected fragments, it was possible to observe 262 histopathological alterations since a single fragment can present more than one lesion.

Regarding sex, 29 dogs were male and 25 were female. Age ranged from one year and three months old to 15 years old, with an average of 9.5 years. When grouped by age group (Fighera et al. 2008), no dogs were younger than oneyear-old (puppy), 39 were between one and nine years old (adult), and 15 dogs were older than nine years old (elderly).
Regarding breeds, mixed-breed dogs were the most frequent $(n=9)$, followed by French Bulldog $(n=4)$, Lhasa Apso $(n=4)$, and Golden Retriever, Maltese, Poodle, Schnauzer, Pug, and Yorkshire Terrier ( $\mathrm{n}=3$ dogs of each breed). The remaining 16 dogs were from nine other breeds.

By direct colonoscopy inspection, the rectum showed the greatest variation in lesions (18), followed by the descending, ascending, and transverse colons (15 each), cecum (10), ileum (8), anus (4), ileocolic valves (3), and cecocolic valve (2). The distributions of the main macroscopic changes diagnosed by the colonoscopy exam are listed in Table 1 and 2 . The most frequent macroscopic lesions were redness, edema, and friability, observed mainly in the rectum, descending colon, transverse colon, ascending colon, and cecum. In the ileum, friability, hemorrhagic focus, and irregular surface were more frequently observed. The main changes in the anus were friability, redness, erosion, and edema, while in the ileocolic and cecocolic valves, friability and edema were mainly observed. The presence of Trichuris sp. in the rectum, descending, transverse, and ascending colons was observed in one dog. All of the aforementioned alterations were present in any nature, shape, and varying degrees, and it is not possible to directly correlate them to a specific nature and endoscopic intensity, as shown in previous studies (Roth et al. 1990, Guilford 2005, Melo et al. 2009, Willard 2012) and by the statistical analysis of the present study.

In the histopathological exams, the descending colon presented a greater variety of lesions (12), followed by the transverse colon and ileum (11), ascending colon (10), rectum (8), cecum (4), and anus (1) (Table 3 and 4). The diversity of microscopic lesions can be present at any portion of the intestine, therefore, they are not specific to a nature or exclusive intestinal segment (Roth et al. 1990, Willard 2012).

Among the histological changes, the lymphoplasmacytic infiltrate was seen in 37 out of 54 dogs (68.52\%) and in all intestinal segments evaluated. When the intestinal segments were considered, the pure lymphoplasmacytic infiltrate was the most frequent alteration in the total of fragments (117/198, 59\%) (Fig.1A,B) and in each intestinal segment analyzed: 17 (48.6\%) of the rectal lesions, 29 (50\%) of the descending colon injuries, 23 (46.9\%) of the transverse colon injuries, 21 (44.6\%) of the ascending colon injuries, nine $(69.2 \%)$ of the cecum injuries, and 18 (51.4\%) of the ileum lesions.

In addition, the lymphoplasmacytic inflammatory infiltrate was observed in conjunction with other types of infiltrate, such as neutrophilic (Fig.1C), eosinophilic, or a mixture of both, in another eight fragments of the descending colon, five fragments of the ascending colon, and two fragments of the ileum. Lymphoplasmacytic colitis and their combination with neutrophils and eosinophils are described as findings in the colonic manifestation of IBD and are, possibly, the main condition observed in this study. However, its diagnosis cannot be based only on histopathological findings and depends on the combination of clinical, laboratory, and colonoscopy findings (Washabau et al. 2010, Uzal et al. 2016). IBD has no specific etiology and is the most common form of colitis described in dogs (Uzal et al. 2016). The variation of inflammatory infiltrates in IBD occurs depending on the chronicity of the lesions, with most cases of chronic lesions characterized by predominant lymphoplasmacytic infiltrates or chronic-active 
Table 1. Classification of the macroscopic lesions and number of lesions observed in segments of anus, rectum, descending colon, transverse colon and ascending colon during the colonoscopy of 54 dogs of Veterinary Hospitals of the "Universidade Federal de Minas Gerais" and São Francisco de Assis, Belo Horizonte/MG, from January 2013 to 0 ctober 2018

\begin{tabular}{|c|c|c|c|c|c|}
\hline \multirow{2}{*}{ Macroscopic lesions } & \multicolumn{5}{|c|}{ Number of lesions ( $\%$ of total in each segment) } \\
\hline & Anus & Rectum & DC & $\mathrm{TC}$ & $\mathrm{AC}$ \\
\hline Reddening & $0(0 \%)$ & $22(16.2 \%)$ & $16(14.8 \%)$ & $13(1.2 \%)$ & $14(13.2 \%)$ \\
\hline Friabilility & $2(40 \%)$ & $21(15.5 \%)$ & $23(21.2 \%)$ & $24(2.3 \%)$ & $23(21.6 \%)$ \\
\hline Enanthema & $1(20 \%)$ & $17(12.5 \%)$ & $12(11.1 \%)$ & $10(9.6 \%)$ & $9(8.4 \%)$ \\
\hline Irregular surface & $0(0 \%)$ & $12(8.8 \%)$ & $11(10.1 \%)$ & $9(8.6 \%)$ & $10(9.4 \%)$ \\
\hline Hemorrhages & $0(0 \%)$ & $8(5.9 \%)$ & $10(9.2 \%)$ & $9(8.6 \%)$ & $9(8.4 \%)$ \\
\hline Hyperreflexia & $0(0 \%)$ & $5(3.7 \%)$ & $0(0 \%)$ & $2(1.9 \%)$ & $3(2.8 \%)$ \\
\hline Folding & $0(0 \%)$ & $4(2.9 \%)$ & $0(0 \%)$ & $0(0 \%)$ & $0(0 \%)$ \\
\hline Reddish pink coloration & $0(0 \%)$ & $3(2.2 \%)$ & $4(3.7 \%)$ & $4(3.8 \%)$ & $5(4.7 \%)$ \\
\hline Whitish coloration & $0(0 \%)$ & $3(2.2 \%)$ & $2(1.8 \%)$ & $2(1.9 \%)$ & $1(0.94 \%)$ \\
\hline Fibrosis & $0(0 \%)$ & $1(0.74 \%)$ & $0(0 \%)$ & $0(0 \%)$ & $0(0 \%)$ \\
\hline Hematoma & $0(0 \%)$ & $1(0.74 \%)$ & $1(0.92 \%)$ & $0(0 \%)$ & $1(0.94 \%)$ \\
\hline Luminal clot & $0(0 \%)$ & $1(0.74 \%)$ & $1(0.92 \%)$ & $2(1.9 \%)$ & $2(1.8 \%)$ \\
\hline Presence of Trichuris sp. & $0(0 \%)$ & $1(0.74 \%)$ & $1(0.92 \%)$ & $1(1.9 \%)$ & $1(0.94 \%)$ \\
\hline Ulceration & $0(0 \%)$ & $0(0 \%)$ & $0(0 \%)$ & $1(1.9 \%)$ & $0(0 \%)$ \\
\hline Velvety surface & $0(0 \%)$ & $0(0 \%)$ & $0(0 \%)$ & $0(0 \%)$ & $0(0 \%)$ \\
\hline
\end{tabular}

$\mathrm{DC}=$ descending colon, $\mathrm{TC}=$ transverse colon, $\mathrm{AC}=$ ascending colon, $\%=$ number of macroscopic lesions over the total number of lesions observed

Table 2. Classification of the macroscopic lesions and number of lesions observed in segments of cecum, cecocolic valve, ileocecal valve and ileum during the colonoscopy of 54 dogs of Veterinary Hospitals of the "Universidade Federal de Minas Gerais" and São Francisco de Assis, Belo Horizonte/MG, from January 2013 to October 2018

\begin{tabular}{|c|c|c|c|c|}
\hline \multirow{2}{*}{ Macroscopic lesions } & \multicolumn{4}{|c|}{ Number of lesions (\% of total in each segment) } \\
\hline & Cecum & $\mathrm{CCV}$ & ICV & Ileum \\
\hline Reddening & $5(15.1 \%)$ & $2(66.6 \%)$ & $7(70 \%)$ & $2(6.4 \%)$ \\
\hline Edema & $4(12.1 \%)$ & $1(33.3 \%)$ & $2(20 \%)$ & $3(9.6 \%)$ \\
\hline Friabilility & $7(21.2 \%)$ & $0(0 \%)$ & $0(0 \%)$ & $7(22.5 \%)$ \\
\hline Enanthema & $1(3.0 \%)$ & $0(0 \%)$ & $0(0 \%)$ & $2(6.4 \%)$ \\
\hline Irregular surface & $2(6.0 \%)$ & $0(0 \%)$ & $0(0 \%)$ & $4(12.9 \%)$ \\
\hline Nodule/mass & $0(0 \%)$ & $0(0 \%)$ & $0(0 \%)$ & $0(0 \%)$ \\
\hline Hemorrhages & $9(27.2 \%)$ & $0(0 \%)$ & $0(0 \%)$ & $4(12.9 \%)$ \\
\hline Hyperreflexia & $0(0 \%)$ & $0(0 \%)$ & $0(0 \%)$ & $1(3.2 \%)$ \\
\hline Folding & $0(0 \%)$ & $0(0 \%)$ & $0(0 \%)$ & $0(0 \%)$ \\
\hline Reddish pink coloration & $2(6.0 \%)$ & $0(0 \%)$ & $0(0 \%)$ & $2(6.4 \%)$ \\
\hline Whitish coloration & $1(3.0 \%)$ & $0(0 \%)$ & $0(0 \%)$ & $0(0 \%)$ \\
\hline Erosion & $1(3.0 \%$ & $0(0 \%)$ & $0(0 \%)$ & $0(0 \%)$ \\
\hline Evident lymphoid follicules & $0(0 \%)$ & $0(0 \%)$ & $0(0 \%)$ & $0(0 \%)$ \\
\hline Presence of mucus & $0(0 \%)$ & $0(0 \%)$ & $0(0 \%)$ & $0(0 \%)$ \\
\hline Fibrosis & $0(0 \%)$ & $0(0 \%)$ & $0(0 \%)$ & $0(0 \%)$ \\
\hline Hematoma & $0(0 \%)$ & $0(0 \%)$ & $1(10 \%)$ & $0(0 \%)$ \\
\hline Luminal clot & $0(0 \%)$ & $0(0 \%)$ & $0(0 \%)$ & $0(0 \%)$ \\
\hline Presence of Trichuris sp. & $0(0 \%)$ & $0(0 \%)$ & $0(0 \%)$ & $0(0 \%)$ \\
\hline Ulceration & $1(3.0 \%)$ & $0(0 \%)$ & $0(0 \%)$ & $0(0 \%)$ \\
\hline Velvety surface & $0(0 \%)$ & $0(0 \%)$ & $0(0 \%)$ & $6(19.3 \%)$ \\
\hline
\end{tabular}

$\mathrm{CCV}=$ cecocolic valve, ICV = ileocecal valve, $\%=$ number of macroscopic lesions over the total number of lesions observed. 
infiltrates characterized by lymphoplasmacytic infiltrates combined with eosinophils or neutrophils (Uzal et al. 2016), as noted in that study.

Table 3. Histopathological diagnoses of inflammatory, proliferative and parasitic changes observed in fragments of anus, rectum, descending colon and transverse colon in the 54 dogs submitted to colonoscopy at Veterinary Hospitals of the "Universidade Federal de Minas Gerais" and São Francisco de Assis, Belo Horizonte/MG, from January 2013 to October 2018

\begin{tabular}{|c|c|}
\hline Histopathological diagnoses & $\begin{array}{l}\text { Number of fragm } \\
\text { (\% of total in each se }\end{array}$ \\
\hline \multicolumn{2}{|l|}{ Anus } \\
\hline Ulcer and neutrophilic infiltrate & $11(100 \%)$ \\
\hline \multicolumn{2}{|l|}{ Rectum } \\
\hline Lymphoplasmocyte proctitis & $17(47.2 \%)$ \\
\hline Erosive/ulcerative proctitis & $6(16.6 \%)$ \\
\hline Suppurative proctitis & $2(5.5 \%)$ \\
\hline Ulcerative histiocytic proctitis & $2(5.5 \%)$ \\
\hline Adenomatous polyp & $6(16.6 \%)$ \\
\hline Carcinoma & $1(1.7 \%)$ \\
\hline Large cell lymphoma & $1(1.7 \%)$ \\
\hline $\begin{array}{l}\text { Presence of intrahistiocytic } \\
\text { Leshmania sp. }\end{array}$ & $1(1.7 \%)$ \\
\hline \multicolumn{2}{|l|}{ Descending colon } \\
\hline Lymphoplasmocyte colitis & $29(50 \%)$ \\
\hline Erosive/ulcerative colitis & $11(18.8 \%)$ \\
\hline $\begin{array}{l}\text { Lymphoplasmocyte and neutrophilic } \\
\text { colitis }\end{array}$ & $5(8.6 \%)$ \\
\hline Eosinophilic colitis & $3(5.1 \%)$ \\
\hline $\begin{array}{l}\text { Lymphoplasmocyte. neutrophilic and } \\
\text { eosinophilic colitis }\end{array}$ & $2(3.4 \%)$ \\
\hline Ulcerative histiocytic colitis & $2(3.4 \%)$ \\
\hline $\begin{array}{l}\text { Lymphoplasmocyte and eosinophilic } \\
\text { colitis }\end{array}$ & $1(1.7 \%)$ \\
\hline $\begin{array}{l}\text { Suppurative colitis with } \\
\text { microthrombosis }\end{array}$ & $1(1.7 \%)$ \\
\hline Eosinophilic and neutrophilic colitis & $1(1.7 \%)$ \\
\hline Carcinoma & $1(1.7 \%)$ \\
\hline Large cell lymphoma & $1(1.7 \%)$ \\
\hline $\begin{array}{l}\text { Presence of intrahistiocytic } \\
\text { Leshmania sp. }\end{array}$ & $1(1.7 \%)$ \\
\hline \multicolumn{2}{|l|}{ Transverse colon } \\
\hline Lymphoplasmocyte colitis & $23(46.9 \%)$ \\
\hline Erosive/ulcerative colitis & $7(14.2 \%)$ \\
\hline $\begin{array}{l}\text { Lymphoplasmocyte and neutrophilic } \\
\text { colitis }\end{array}$ & $5(10.2 \%)$ \\
\hline Eosinophilic colitis & $3(6.1 \%)$ \\
\hline Eosinophilic and neutrophilic colitis & $3(6.1 \%)$ \\
\hline Ulcerative histiocytic colitis & $2(4.0 \%)$ \\
\hline Suppurative colitis & $1(2.0 \%)$ \\
\hline $\begin{array}{l}\text { Lymphoplasmocyte colitis with } \\
\text { hemorrhage and fibrin }\end{array}$ & $1(2.0 \%)$ \\
\hline Small cell lymphoma & $2(4.0 \%)$ \\
\hline Large cell lymphoma & $1(2.0 \%)$ \\
\hline $\begin{array}{l}\text { Presence of intrahistiocytic } \\
\text { Leshmania sp. }\end{array}$ & $1(2.0 \%)$ \\
\hline
\end{tabular}

$\%=$ number of fragments with lesion over the total number of fragments observed.
Intestinal lymphangiectasia was observed in 18 dogs with inflammatory changes. Of these, all had lymphoplasmacytic infiltrate in the ileum, but the lesion was not always restricted to this organ. This finding is commonly observed in chronic gastrointestinal lesions (Kleinschmidt et al. 2006, Sherding \& Johnson 2006, Maeda et al. 2012, Rossi et al. 2015). This lesion is clinically relevant because it is usually associated with protein loss and malabsorption. In cases of IBD, the most likely cause of this change is the obstruction of lymph vessels by an inflammatory infiltrate (Kleinschmidt et al. 2006, Larson et al. 2012, Craven \& Washabau 2019).

For all inflammatory changes, colonoscopy findings included mainly redness or blackening, whitish color, edema, enanthem, friability, evident lymphoid follicles, granular appearance, or hyperreflexia.

Table 4. Histopathological diagnoses of inflammatory, proliferative and parasitic changes observed in the fragments of ascending colon, cecum and ileum in the 54 dogs submitted to colonoscopy at Veterinary Hospitals of the "Universidade

Federal de Minas Gerais" and São Francisco de Assis, Belo Horizonte/MG, from January 2013 to October 2018

\begin{tabular}{|c|c|}
\hline Histopathological diagnoses & $\begin{array}{c}\text { Number of fragments } \\
\text { (\% of total in each segment) }\end{array}$ \\
\hline \multicolumn{2}{|l|}{ Ascending colon } \\
\hline Lymphoplasmocyte colitis & $21(44.6 \%)$ \\
\hline Erosive/ulcerative colitis & $7(14.8 \%)$ \\
\hline $\begin{array}{l}\text { Lymphoplasmocyte and neutrophilic } \\
\text { colitis }\end{array}$ & $5(10.6 \%)$ \\
\hline Eosinophilic colitis & $4(8.5 \%)$ \\
\hline Eosinophilic and neutrophilic colitis & $3(6.3 \%)$ \\
\hline Ulcerative histiocytic colitis & $2(4.2 \%)$ \\
\hline Suppurative colitis & $1(2.1 \%)$ \\
\hline Small cell lymphoma & $2(4.2 \%)$ \\
\hline Large cell lymphoma & $1(2.1 \%)$ \\
\hline Presence of intrahistiocytic Leshmania sp. & $1(2.1 \%)$ \\
\hline \multicolumn{2}{|l|}{ Cecum } \\
\hline Lymphoplasmocytic typhlitis & $9(69.2 \%)$ \\
\hline Eosinophilic typhlitis & $2(15.3 \%)$ \\
\hline $\begin{array}{l}\text { Neutophilic typhlitis with lymphoid } \\
\text { hyperplasia }\end{array}$ & $1(7.6 \%)$ \\
\hline $\begin{array}{l}\text { Lymphoplasmocyt typhilits with } \\
\text { multifocal microerosion }\end{array}$ & $1(7.6 \%)$ \\
\hline \multicolumn{2}{|l|}{ Ileum } \\
\hline $\begin{array}{l}\text { Lymphoplasmocytic ileitis with } \\
\text { lymphangiectasis }\end{array}$ & $18(51.4 \%)$ \\
\hline Neutrophilic ileitis & $6(17.1 \%)$ \\
\hline Eosinophilic ileitis & $2(5.7 \%)$ \\
\hline $\begin{array}{l}\text { Lymphoplasmocytic and eosinophilic } \\
\text { ileitis }\end{array}$ & $2(5.7 \%)$ \\
\hline Lymphocytic ileitis & $1(2.8 \%)$ \\
\hline Neutrophilic and eosinophilic ileitis & $1(2.8 \%)$ \\
\hline Ulcerative ileitis & $1(2.8 \%)$ \\
\hline Small cell lymphoma & $1(2.8 \%)$ \\
\hline Large cell lymphoma & $1(2.8 \%)$ \\
\hline Undifferentiated round cell neoplasm & $1(2.8 \%)$ \\
\hline Presence of intrahistiocytic Leshmania sp. & $1(2.8 \%)$ \\
\hline
\end{tabular}
observed. 


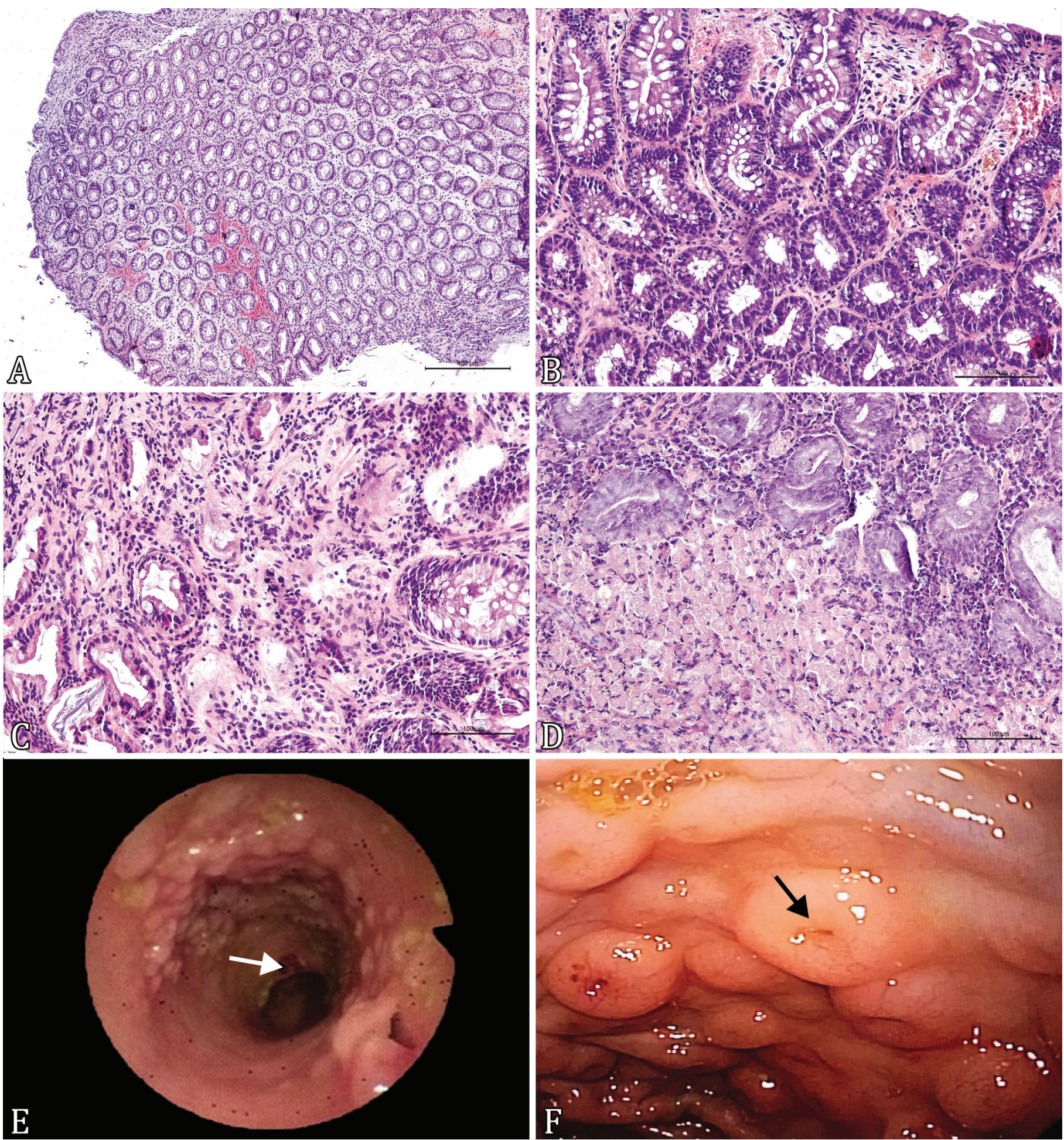

Fig.1. (A) Mild lymphoplasmacytic colitis, descending colon, dog. Small numbers of lymphocytes and plasma cells infiltrate the lamina propria (arrow). Crypts (arrowhead) and venules (asterisk) show no histologic changes. HE, obj.4x. (B) Mild lymphoplasmacytic colitis, rectum, dog. Small numbers of lymphocytes and plasma cells infiltrate the lamina propria (arrow). Crypts (arrowhead) are mildly attenuated and venules (asterisk) show no histologic changes. HE, obj.10x. (C) Moderate lymphoplasmacytic and neutrophilic colitis, transverse colon, dog. Moderate numbers of lymphocytes, plasma cells and neutrophils infiltrate the lamina propria (arrow). Crypts (arrowhead) are mildly attenuated and venules (asterisk) show no histologic. HE, obj.20x. (D) Ulcerative and histiocytic colitis, descending colon, French Bulldog dog. Moderate numbers of lymphocytes and plasma cells admixed with aggregates of histiocytes infiltrate and expand the lamina propria. the histiocytes are swollen and contain moderate amount of an intracytoplasmic eosinophilic and granular material. HE, obj.20x. (E) Colonoscopic image of the rectum and descending colon of a dog with adenomatous polyps. Note the mucosa with diffuse sessile protrusions and area of erosion (white arrow). (F) Colonoscopic image of the descending colon of a dog with moderate lymphoplasmacytic colitis. Note the swollen mucosa and evident lymphoid follicles (black arrow). 
Another frequent finding was ulcerative and erosive colitis. When considering the intestinal segments, these changes represented six (16.2\%) of the changes in the rectum, $11(18.6 \%)$ in the descending colon, seven $(13.4 \%)$ in the transverse colon, seven (14.5\%) in the ascending colon, and one $(1.8 \%)$ in the ileum. Microerosions and ulcers are also associated with the colonic manifestation of IBD and, due to the chronicity of the lesion, often show collagen deposition in the lamina propria and a reduction in the number of inflammatory cells. In some cases, there is an abundance of neutrophils and necrotic material in the areas underlying these lesions, which hinders their association with this condition (Uzal et al. 2016). Both presentations were observed in the samples evaluated in the present study.

The only eosinophilic infiltrate was observed in four dogs, or in three $(5.1 \%)$ lesions of the descending colon, three $(5.7 \%)$ of the transverse colon, four $(8.3 \%)$ of the ascending colon, two (15.4\%) of the cecum, and two (3.5\%) of the ileum. This type of infiltrate correlates to parasitic infestation and food allergy or intolerance (Parnell 2009). The first (infestation by Trichuris sp.) was observed in one dog in the present study. In these cases, changes such as erythema, edema, friability, and hemorrhagic areas were also seen, as reported by Hilton et al. (2002) and Dossin \& Henroteaux (2004), albeit without significant correlation with histopathological findings. Noteworthy, the observation of this type of infiltrate on biopsies is not pathognomonic for food allergy (Uzal et al. 2016).

Granulomatous infiltration was seen in the rectum, colon segments, and cecum. This is a rare condition that can affect mainly the ileum and the rectum but is seldom observed in the cecum (German et al. 2000), in contrast with the findings of this study. In none of the cases of granulomatous lesions it was possible to observe pathogens that could be related to this lesion.

Infiltrations that were solely neutrophilic were a less common finding in the intestinal segments analyzed. In one of these cases, Clostridium difficile enterotoxins A and B were detected by complementary tests, such as fecal microbiota analysis, which demonstrated dysbiosis, a finding already reported in infections by bacteria of the genus Clostridium (Simpson \& Jergens 2011, Minamoto et al. 2014, Suchodolski 2016).

Although uncommon, two cases of HUC were observed in French Bulldogs with lesions concentrated in the rectum and descending colon and histopathological findings similar to previous reports of the disease (Fig.1D) (Tanaka et al. 2003, Mansfield et al. 2009, Pavarini et al. 2011, Argenta et al. 2018). PAS staining performed herein demonstrated the accumulation of granular eosinophilic material in the macrophage cytoplasm in the lamina propria. This condition is believed to be a hereditary anomaly related to the susceptibility of some dog breeds to invasion by a group of Escherichia coli since a greater quantity of this bacterium is observed in cases of the disease and antibiotic therapy shows good results in its treatment (Mansfield et al. 2009, Pavarini et al. 2011). The colonoscopy findings of the cases of this study showed edema, irregular surface hyperemic, more evident lymphoid follicles, ulcerations, and hemorrhagic areas, similar to the macroscopic findings described for this disease (Sherding 2003, Parnell 2009).

Regarding proliferative changes, three main types were observed: lymphoma, carcinoma, and polyps. The rectum was the intestinal segment most affected by these changes, followed by the ileum, descending colon, transverse colon, and ascending colon, which is similar to the distribution of these changes described in the literature (Sherding 2003, Baba \& Câtoi 2007). Intestinal lymphoma (five large cells and four small cells) was described in nine colonoscopy reports, three of which were located in the rectum, three in the colon, and three in the ileum. By colonoscopy, these proliferations were characterized by a mass aspect or focal/ diffuse nodulations. Six hyperplastic polyps were identified (Fig.1E) and were classified by histopathological examination as tubular, with no potential for malignancy, when compared to villous and tubulovillous polyps (Morson 1974). The main sites of occurrence of the polyps were the rectum and the descending colon, similar to what has been described in a study with miniature Dachshund dogs (Ohmi et al. 2011). The cases of carcinoma observed in this study were found in the rectum and the descending colon of a dog.

Among the infectious causes, we observed the occurrence of Trichuris sp. and of amastigotes of Leishmania spp. The observation of Leishmania spp. in segments of the intestine was described in a recent study that demonstrated its association with chronic colitis, characterized by lymphoplasmacytic or histiocytic infiltrate in endemic areas of the infection (Casanova et al. 2019).

According to Brandt \& Aroniadis (2013), the form and the number of endoscopic and histopathological lesions can be related to the severity and duration of the disease in the patient. In the present study, the history of various diseases and treatments, of different durations, prior to the colonoscopy exam may have influenced the quantity and distribution of the endoscopic and histopathological lesions described. We observed a moderate agreement between the classification of the nature of the findings by endoscopy and histopathology (Kappa coefficient $=0.39, \mathrm{CI}=0.20-0.59$ ). . This can also be observed when assessing the frequency of similar diagnoses between the methods, since only $39(72.22 \%)$ were consistent, i.e., 15 (22.78\%) diagnoses differed depending on the nature of the finding, which could have a great influence on the final diagnosis if histopathology was disregarded. The inflammatory nature by endoscopic examination (Table 5) was observed in 39 dogs (72.22\%), and the histopathological examination indicated 30 dogs (55.56\%) with inflammatory lesions, two (3.70\%) with associated lesions of inflammation and neoplasia, and seven $(12.96 \%)$ without microscopic alterations. The inflammatory and neoplastic endoscopic nature was observed in seven dogs (12.96\%), five (9.26\%) of which showed coincident results by histopathological examination, while two $(3.70 \%)$ showed no change. The neoplastic endoscopic nature was described in three (5.56\%) dogs, of which one $(1.85 \%)$ was identified as inflammatory by histopathological examination, one $(1.85 \%)$ as inflammatory and neoplastic, and one (1.85\%) as neoplastic. For the endoscopic nature of undefined cause, one case (1.85\%) coincided with the histopathological examination. Absence of endoscopic changes was described in four (7.41\%) dogs, of which two $(3.7 \%)$ showed coincident histopathological results and two (3.7\%) were of inflammatory nature. This fact corroborates the findings by Roth et al. (1990) that it is not always possible to associate the visible changes in the two methods and the findings of Guilford (2005), which show that injuries can be 
considered nonspecific when attributed to an exclusive nature. On the other hand, Cascon et al. (2017) describe a stronger relationship between endoscopic changes, histopathological examination, and clinical signs when it comes to IBD. In the present study, in addition to the inflammatory nature, other natures such as neoplastic, of an undefined cause, mixed interactions, and the normal pattern were included and equated, and direct associations could not be proved.

Regarding the macroscopic changes, edema, hyperreflexia, mucus, evident diffuse lymphoid follicles (Fig.1F), and hyperemic areas were observed in dogs with only the lymphoplasmacytic infiltrate or mixed infiltrates, as described by Jergens \& Zoran (2005).

In terms of the intensity of the injuries (Table 6), little agreement was observed between the methods (Kappa coefficient $=0.1243$, $\mathrm{CI}=-0.05-0.30$ ). This was even more evident in the frequency of similar diagnoses in terms of intensity, of which 20 (37.04\%) were similar and 34 (62.96\%) were different, as reported by Roth etal. (1990). It is not always possible to associate the changes seen by the two methods since the macroscopic absence of the lesion does not necessarily indicate normality, even if the condition presents itself in a severe stage. This disadvantage of the colonoscopy can lead to false-negative results if the test is performed alone. Nevertheless, this technique has the advantage of allowing for the collection of tissue samples, which are recommended to obtain the definitive diagnosis. Therefore, one can conclude that both methods of this study are complementary and should always be used in combination.

\section{CONCLUSIONS}

Inflammatory affections are the most frequently observed alterations in the large intestine and ileum of dogs by colonoscopy and histopathological examination.

The most common finding that reveals inflammatory changes is the lymphoplasmacytic infiltrate. As for the proliferative and neoplastic lesions, adenomatous polyps and lymphoma were common.

The most affected sites of the large intestine were the descending colon and the rectum, regions that should always be inspected and biopsied.

Table 5. Frequency of classification regarding the endoscopic and histopathological nature of the 54 reports of dogs submitted to colonoscopy at the Veterinary Hospitals of the "Universidade Federal de Minas Gerais" and São Francisco de Assis, Belo Horizonte/MG, from January 2013 to October of 2018

\begin{tabular}{|c|c|c|c|c|c|c|}
\hline \multirow[b]{2}{*}{ Endoscopic nature * } & \multicolumn{6}{|c|}{ Histopathological nature* } \\
\hline & Inflammatory & $\begin{array}{l}\text { Inflammatory } \\
\text { and neoplastic }\end{array}$ & $\begin{array}{l}\text { Inflammatory and } \\
\text { indefinite cause }\end{array}$ & Neoplastic & Unchanged & Total \\
\hline \multirow[t]{2}{*}{ Inflammatory } & 30 & 2 & 0 & 0 & 7 & 39 \\
\hline & 55.56 & 3.70 & 0.00 & 0.00 & 12.96 & 72.22 \\
\hline \multirow[t]{2}{*}{ Inflammatory and neoplastic } & 0 & 5 & 0 & 0 & 2 & 7 \\
\hline & 0.00 & 9.26 & 0.00 & 0.00 & 3.70 & 12.96 \\
\hline \multirow[t]{2}{*}{ Neoplastic } & 1 & 1 & 0 & 1 & 0 & 3 \\
\hline & 1.85 & 1.85 & 0.00 & 1.85 & 0.00 & 5.56 \\
\hline \multirow[t]{2}{*}{ Indefinite cause } & 0 & 0 & 1 & 0 & 0 & 1 \\
\hline & 0.00 & 0.00 & 1.85 & 0.00 & 0.00 & 1.85 \\
\hline \multirow[t]{2}{*}{ Unchanged } & 2 & 0 & 0 & 0 & 2 & 4 \\
\hline & 3.70 & 0.00 & 0.00 & 0.00 & 3.70 & 7,41 \\
\hline \multirow[t]{2}{*}{ TOTAL } & 33 & 8 & 1 & 1 & 11 & 54 \\
\hline & 61.11 & 14.81 & 1.85 & 1.85 & 20.37 & 100.00 \\
\hline
\end{tabular}

* For each category of nature the first line corresponds to the absolute frequency and the second line to the relative frequency.

Table 6. Frequency of classification regarding endoscopic and histopathological graduation of 54 dogs, colonoscopy at Veterinary Hospitals of the "Universidade Federal de Minas Gerais" and São Francisco de Assis, Belo Horizonte/MG, from January 2013 to October 2018

\begin{tabular}{|c|c|c|c|c|c|}
\hline \multirow{2}{*}{ Endoscopic graduation* } & \multicolumn{5}{|c|}{ Histopathological graduation* } \\
\hline & Absent & Mild & Moderate & Intense & Total \\
\hline \multirow[t]{2}{*}{ Absent } & 4 & 5 & 4 & 1 & 14 \\
\hline & 7.41 & 9.26 & 7.41 & 1.85 & 25.93 \\
\hline \multirow[t]{2}{*}{ Mild } & 3 & 6 & 8 & 1 & 18 \\
\hline & 5.56 & 11.11 & 14.81 & 1.85 & 33.33 \\
\hline \multirow[t]{2}{*}{ Moderate } & 3 & 4 & 10 & 2 & 19 \\
\hline & 5.56 & 7.41 & 18.52 & 3.7 & 35.19 \\
\hline \multirow[t]{2}{*}{ Intense } & 0 & 0 & 2 & 1 & 3 \\
\hline & 0 & 0 & 3.7 & 1.85 & 5.56 \\
\hline \multirow[t]{2}{*}{ TOTAL } & 10 & 15 & 24 & 5 & 54 \\
\hline & 18.52 & 27.78 & 44.44 & 9.26 & 100 \\
\hline
\end{tabular}

* For each graduation category, the first line corresponds to the absolute frequency and the second line to the relative frequency. 
Findings such as edema and reddening of the mucosa were frequent by macroscopy.

Nevertheless, these findings were present in alterations of any nature.

Although the changes observed by colonoscopy and histopathology may not be similar, these techniques are complementary, which makes biopsies mandatory for a diagnostic conclusion.

Conflict of interest statement.- The authors declare that there is no conflict of interest in the publication of this article.

\section{REFERENCES}

AlShawaqfeh M.K., Wajid B., Minamoto Y., Markel M., Lidbury J.A., Steiner J.M., Serpedin E. \& Suchodolski J.S. 2017. A dysbiosis index to assess microbial changes in fecal samples of dogs with chronic inflammatory enteropathy. FEMS Microbiol. Ecol. 93(11):136. <https://dx.doi.org/10.1093/femsec/ fix136><PMid:29040443>

Argenta F.F., Souza S.O., Meirelles L.S., Snel G.G.N., De Lorenzo G., IenesLima J., Forn F., Drimeier D. \& Pavarini S.P. 2018. Histiocytic ulcerative colitis in a American Staffordshire Terrier. J. Comp. Pathol. 165:40-44. <https://dx.doi.org/10.1016/j.jcpa.2018.09.006><PMid:30502794>

Baba A.I \& Câtoi C. 2007. Tumors of the alimentary system. Comparative Oncology, The Publishing House of the Romanian Academy, Bucharest. Available at <https://www.ncbi.nlm.nih.gov/books/NBK9565/> Accessed on Oct. 31, 2018.

Brandt L.J. \& Aroniadis O.C. 2013. An overview of fecal microbiota transplantation: techniques, indications, and outcomes. Gastrointest. Endosc. 78(2):240249. <https://dx.doi.org/10.1016/j.gie.2013.03.1329><PMid:23642791>

Casanova M.I., Martin S., Marco A. \& Sollano-Galego L. 2019. Detection of Leishmania spp. infection by immunohistochemistry in archived biopsy samples from dogs with colitis in an area endemic for leishmaniosis. J. Comp. Pathol. 167:12-17.<https://dx.doi.org/10.1016/j.jcpa.2018.11.005> <PMid:30898292>

Cascon C.M., Mello M.F.V., Leite J.S. \& Ferreira A.M.R. 2017. Avaliação clínica, endoscópica e histopatológica de cães com doença inflamatória intestinal. Pesq. Vet. Bras. 37(11):1287-1297. <https://dx.doi.org/10.1590/s0100736x2017001100015>

Craven M.D. \& Washabau R.J. 2019. Comparative pathophysiology and management of protein-losing enteropathy. J. Vet. Intern. Med. (33):383402. <https://dx.doi.org/10.1111/jvim.15406><PMid:30762910>

Day M.J., Bilzer T., Mansell J., Wilcock B., Hall E.J., Jergens A., Minami T., Willard M. \& Washabau R. 2008. Histopathological standards for the diagnosis of gastrointestinal inflammation in endoscopic biopsy samples from the dog and cat: a report from the world small animal veterinary association gastrointestinal standardization group. J. Comp. Pathol.138(Supl.1):S1-S43. <https://dx.doi.org/10.1016/j.jcpa.2008.01.001><PMid:18336828>

Dossin 0. \& Henroteaux M. 2004. Como abordar diagnóstico e tratamento da doença inflamatória intestinal em cães. Waltham Focus 14(1):19-24.

Elwood C. 2003. Investigation and differential diagnosis of vomiting in the dog. In Practice 25(7):374-386. <https://dx.doi.org/10.1136/inpract.25.7.374>

Fighera R.A., Souza T.M., Silva M.C., Brum J.S., Graça D.L., Kommers G.D., Irigoyen L.F. \& Barros C.S.L. 2008. Causas de morte e razões para eutanásia de cães da Mesorregião do Centro Ocidental Rio Grandense (1965-2004). Pesq. Vet. Bras. 28(4):223-230. <https://dx.doi.org/10.1590/S0100736X2008000400005>

German A.J., Hall E.J., Kelly D.F., Watsond A.D.J. \& Day M.J. 2000. An immunohistochemical study of histiocytic ulcerative colitis in boxer dogs. J. Comp. Pathol. 122(2/3):163-175. <https://dx.doi.org/10.1053/ jcpa.1999.0353><PMid:10684685>
Guilford W.G. 2005. Upper gastrointestinal endoscopy, p.279-321. In: McCarthy T.C. \& Constantinescu G.M. (Eds), Veterinary Endoscopy for the Small Animal Practitioner. Elsevier Saunders, Philadelphia.

Hilton L.E., Mcloughlin M.A., Johnson S.E. \& Weisbrode S.E. 2002. Spontaneous gastroduodenal perforation in 16 dogs and seven cats (1982-1999). J. Am. Anim. Hosp. Assoc. 38(2):176-187.<https://dx.doi.org/10.5326/0380176> $<$ PMid:11908837>

Jergens A.E. \& Zoran D.L. 2005. Diseases of the colon and rectum, p.203-212. In: Hall E.J., Simpson J.W. \& Williams D.A. (Eds), BSAVA Manual of Canine and Feline Gastroenterology. 2nd ed. British Small Animal Veterinary Association, Gloucester.

Jergens A.E., Schreiner C.A., Frank D.E., Niyo Y., Ahrens F. E., Eckersall P.D., Benson T.J. \& Evans R. 2003. A scoring index for disease activity in canine inflammatory bowel disease. J. Vet. Intern. Med. 17(3):291-297. <https://dx.doi.org/10.1111/j.1939-1676.2003.tb02450.x><PMid:12774968>

Kleinschmidt R., Meneses F., Nolte I. \& Hewicker-Trautwein M. 2006. Retrospective study on the diagnostic value of full-thickness biopsies from the stomach and intestines of dogs with chronic gastrointestinal disease symptoms. Vet. Pathol. 43(6):1000-1003. <https://dx.doi.org/10.1354/ vp.43-6-1000><PMid:17099159>

Larson R.N., Ginn J.A., Bell C.M., Davis M.J. \& Foy D.S. 2012. Duodenal endoscopic findings and histopathologic confirmation of intestinal lymphangiectasia in dogs. J. Vet. Intern. Med. 26(5):1087-1092. <https://dx.doi.org/10.1111/j.1939-1676.2012.00970.x><PMid:22827501>

Maeda S., Ohno K., Nakamura K., Uchida K., Nakashima K., Fukushima K., Tsukamoto A., Goto-Koshino Y., Fujino Y. \& Tsujimoto H. 2012. Mucosal imbalance of interleukin-1 b and interleukin-1 receptor antagonist in canine inflammatory bowel disease. Vet. J. 194(1):66-70. <https://dx.doi. org/10.1016/j.tvjl.2012.02.026><PMid:22483380>

Mansfield C.S., James F.F., Craven M., Davies D.R., O'hara A.J., Nicholls P.K., Dogan B., MacDonough S.P. \& Simpson K.W. 2009. Remission of histiocytic ulcerative colitis in Boxer dogs correlates with eradication of invasive intramucosal Escherichia coli. J. Vet. Intern. Med. 23(5):964-969. <https:// dx.doi.org/10.1111/j.1939-1676.2009.0363.X> <PMid:19678891>

Melo M.M., Cury P.M., Ronchi L.S., Gonçalves-Filho F.A., Cunrath G.S. \& Netinho J.G. 2009. Terminal ileum of patients who underwent colonoscopy: endoscopic, histologic and clinical aspects. Arq. Gastroenterol. 46(2):102106. <https://dx.doi.org/10.1590/S0004-28032009000200005>

Miki Jr P., Rocha J.J.R., Aprilli F. \& Féres 0. 2002. Estudo comparativo entre as soluções de manitol, picossulfato de sódio e fosfato monobásico e dibásico de sódio no preparo de cólon para colonoscopia. Acta Cir. Bras. 17(Supl.3):6468. <https://dx.doi.org/10.1590/S0102-86502002000900014>

Minamoto Y., Dhanani N., Markel M.E., Steiner J. \& Suchodolsky J.S. 2014. Prevalence of Clostrium perfringens, Clostridium perfringens enterotoxin and dysbiosis in fecal samples of dogs with diarrhea. Vet. Microbiol. 174(3/4):463-473. <https://dx.doi.org/10.1016/j.vetmic.2014.10.005> $<$ PMid:25458422>

Morson B. 1974. The polyp-cancer sequence in the large bowel. Proc. R. Soc. Med. 67(6 Pt 1):451-457. <PMid:4853754>

Nahas S.C., Marques C.F.S., Araújo S.A., Aisaka A.A., Nahas C.S.R., Pinto R.A. \& Kiss D.R. 2005. Colonoscopia como método diagnóstico e terapêutico das moléstias do intestino grosso: análise de 2567 exames. Arq. Gastroenterol. 42(2):77-82. <https://dx.doi.org/10.1590/S0004-28032005000200003>

Ohmi A., Ttsukamoto A., Oohno K., Uchida K., Nishimura R., Fukushima K., Takahashi M., Nakashima K., Fujino Y. \& Tsujimoto H. 2011. A retrospective study of inflammatory colorectal polyps in miniature dachshunds. J. Vet. Med. Sci. 74(1):59-64. <https://dx.doi.org/10.1292/jvms.11-0352> <PMid:21897060>

Parnell N.K. 2009. Gastrointestinal diseases: chronic colitis, p.515-520. In: Bonagura J.D. \& Twedt D.C. (Eds), Kirk's Current Veterinary Therapy. 14th ed. Saunders Elsevier, Philadelphia. 
Pavarini S.P., Gomes D.C., Bandinelli M.B., Oliveira E.C., Bandarra P.M., Cruz C.E.F. \& Driemeier D. 2011. Colite histiocítica ulcerativa em um cão Boxer no Brasil. Acta Scient. Vet. 39(3):1-5.

Rossi G., Cerquetella M., Antonelli E., Pengo G., Magi G.E., Villanacci V., RostamiNejad M., Spaterna A. \& Bassotti G. 2015. The importance of histologic parameters of lacteal involvement in cases of canine lymphoplasmacytic enteritis. Gastroenterol. Hepatol. Bed Bench 8(1):33-41.<PMid:25584174>

Roth L., Leib M.S., Davenport D.J. \& Monroe W. 1990. Comparisons between endoscopic and histologic evaluation of the gastrointestinal tract in dogs and cats: 75 cases (1984-1987). J. Am. Vet. Med. Assoc. 196(4):635-638. <PMid:2303390>

Santos C.H.M., Cury M.D.S. \& Saad F.T. 2009. Principais achados de colonoscopias realizadas em caráter de urgência e eletivas. Revta Bras. Colo-Proctol. 29(1):83-87.<https://dx.doi.org/10.1590/S0101-98802009000100012>

SAS 2018. SAS University Edition User's Guide. SAS Institute Inc., Cary, NC.

Sherding R.G. \& Johnson S.E. 2006. Diseases of the intestines, p.702-738. In: Birchard S.J. \& Sherding R.G. (Eds), Saunders Manual of Small Animal Practice. 3rd ed. Elsevier Saunders, St. Louis.

Sherding R.G. 2003. Diseases of the large intestine, p.251-281. In: Tams T.R. (Ed.), Handbook of Small Animal Gastroenterology. 2nd ed. W.B. Saunders, Philadelphia.

Silva A.C., Pimenta M. \& Guimarães L.S. 2009. Small bowel obstruction: what to look for. RadioGraphics. 29(2):423-439. <https://dx.doi.org/10.1148/ rg.292085514>

Simpson K.W. \& Jergens A.E. 2011. Pitfalls and progress in the diagnosis and management of canine inflammatory bowel disease. Vet. Clin. N.
Am., Small Anim. Pract. 41(2):381-398. <https://dx.doi.org/10.1016/j. cvsm.2011.02.003 > <PMid:21486642>

Suchodolski J.S. 2016. Diagnosis and interpretation of intestinal dysbiosis in dogs and cats. Vet. J. 215:30-37. <https://dx.doi.org/10.1016/j. tvjl.2016.04.011><PMid:27160005>

Tanaka M., Nakayama M. \& Takase K. 2003. Histiocytic ulcerative colitis in a french bulldog. J. Vet. Med. Sci. 65(3):431-433.<https://dx.doi.org/10.1292/ jvms.65.431><PMid:12679583>

Uzal F.A., Plattner B.L. \& Hostetter J.M. 2016. Alimentary system, p.205-216. In: Maxie M.G. (Ed.), Jubb, Kennedy, and Palmer's Pathology of Domestic Animals. Vol.2. 6th ed. Elsevier, St Louis. 654p.

Washabau R.J., Day M.J., Willard M.D., Hall E.J., Jergens A.E., Mansell J., Minami T. \& Bilzer T.W.2010. Endoscopic, biopsy, and histopathologic guidelines for the evaluation of gastrointestinal inflammation in companion animals. J. Vet. Intern. Med. (24):10-26. <https://dx.doi.org/10.1111/j.1939-1676.2009.0443.x> <PMid:20391635>

Willard M.D. 2012. Alimentary neoplasia in geriatric dogs and cats. Vet. Clin. N. Am., Small Anim. Pract. 42(4):693-706. <https://dx.doi.org/10.1016/j. cvsm.2012.04.006><PMid:22720809>

Willard M.D., Mansell J.M., Fosgate G.T., Gualtieri M., Olivero D., Lecoindre P., Twedt D.C., Collett M.G., Day M.J., Hall E.J., Jergens A.E., Simpson J.W., Else R.W. \& Washabau R.J. 2008. Effect of sample quality on the sensitivity of endoscopic biopsy for detecting gastric and duodenal lesions in dogs and cats. J. Vet. Intern. Med. 22(5):1084-1089. <https://dx.doi. org/10.1111/j.1939-1676.2008.0149.x> <PMid:18638017> 